MACIEL, GM; FINZI, RR; CARVALHO, FJ; MARQUEZ, GR; CLEMENTE, AA. 2018. Agronomic performance and genetic dissimilarity among cherry tomato genotypes. Horticultura Brasileira 36: 167-172. http://dx.doi.org/10.1590/S0102-053620180203

\title{
Agronomic performance and genetic dissimilarity among cherry tomato genotypes
}

\section{Gabriel M Maciel; Rafael R Finzi; Fábio J Carvalho; Guilherme R Marquez; Andressa A Clemente}

Universidade Federal de Uberlândia (UFU), Monte Carmelo-MG, Brazil; gabrielmaciel@ufu.br; rafaelfinzi@hotmail.com; fabiojanoni@ ufu.br; grepeza@gmail.com; andressalves50@gmail.com

\begin{abstract}
The genotypes evaluation in a germplasm bank is essential to determine their commercial or usefulness, as potential parents, in a breeding program. We aimed to detect the genetic diversity of 42 tomato genotypes of cherry type, belonging to the germplasm bank of the Federal University of Uberlândia and, also evaluate their behavior. The experiment was conducted in a greenhouse in randomized block design with 42 treatments and two replications. Ten quantitative traits of agronomic importance were evaluated. The genetic divergence was obtained by multivariate analysis, using the Mahalanobis distance with different clustering methods (UPGMA and Tocher). The hybrids performance was compared by Scott-Knott $(\mathrm{p}=$ $0.05)$ and Dunnett's test $(p=0.05)$. UPGMA and Tocher grouped the genotypes similarly, representing genetic divergence satisfactorily. The genotypes UFU 29, UFU 21 and UFU 07 were more productive, earlier and also divergent from the pre-commercial treatment (UFU 200), being able to be used as potential parents.
\end{abstract}

Keywords: Solanum lycopersicum, variability, grape tomato.

\section{RESUMO}

Desempenho agronômico e dissimilaridade genética entre genótipos de tomate cereja

A avaliação de genótipos em um banco de germoplasma é essencial para determinar seu potencial comercial ou sua utilidade como potenciais genitores em um programa de melhoramento. Assim, o objetivo do trabalho foi verificar a divergência genética e o comportamento per se de 42 genótipos de tomate cereja pertencentes ao banco de germoplasma de tomateiro da Universidade Federal de Uberlândia. $\mathrm{O}$ experimento foi conduzido em casa de vegetação no delineamento experimental de blocos casualizados, com 42 tratamentos e duas repetições. Foram avaliados dez caracteres quantitativos de importância agronômica. A divergência genética foi obtida por meio de análises multivariadas utilizando-se a distância generalizada de Mahalanobis, empregando-se diferentes métodos de agrupamento (UPGMA e Tocher). O desempenho dos híbridos foi comparado pelos testes Scott-Knott $(p=0,05)$ e Dunnett $(p=0,05)$. Os métodos UPGMA e Tocher agruparam os genótipos de forma semelhante, sendo satisfatórios para representar a divergência genética. Os genótipos UFU 29, UFU 21 e UFU 07 foram mais produtivos, precoces e também divergentes à testemunha UFU 200, podendo ser utilizados como possíveis genitores.

Palavras-chave: Solanum lycopersicum, variabilidade, tomate do tipo grape.

\section{Received on October 24, 2016; accepted on November 14, 2017}

$\mathrm{T}$ omato cropping has been highlighted, over the years, as one of the most important agricultural activities in Brazil. In 2012, over 69.000 hectares of tomato were cultivated in Brazil. Beyond that, only the seed market reached R\$ 124 million (ABCSEM, 2014). In addition, tomato cropping has an amazing importance on social sphere, using, basically, manual managements and in the feeding sphere, presenting great nutritional components (Alvarenga, 2013).

The tomato presents a huge fruit diversity, which makes it to be classified in commercial groups: Cherry, Grape, Santa Cruz, Italian, Round, Saladette and Industrial (Alvarenga, 2013). Among these, cherry tomatoes present small fruits and a sweeter taste in relation to the other groups. These minitomatoes are quite new on the supermarkets, but have one of the greatest potential for expansion, for presenting different flavors and colors and for its practicality (Maciel et al., 2016). Being the cultivation meticulous, the cherry cropping demands a high initial cost and a skilled labor (Alvarenga, 2013). Nevertheless, the activity is a good option for new investors due to its high added value (Abrahão et al., 2014).

Since the main cherry tomatoes are produced from hybrid seeds (Maciel et al., 2016), breeding strategies consist in exploiting heterosis to detect important agronomic characteristics, as productivity, plagues and disease resistance and precocity. Being the heterotic effect pronounced, there is a need of genetic divergence between parents; the higher the difference 
between the alleles, greater the heterosis effect (Borém \& Miranda, 2009).

So, the variability between parents can be estimated using measures of genetic dissimilarity, highlighting the generalized distance of Mahalanobis $\left(D_{i i^{i}}^{2}\right)$ that considers the residual variances and covariances existing between quantitative characters (Cruz et al., 2012).Tocher and UPGMA methods are constantly used to check this divergence on tomato cropping (Gonçalves et al., 2008; Mattedi et al., 2014; Araújo et al., 2016).

Due to the market expansion of cherry tomato seeds and the increasing search for new hybrids, new studies are necessary to develop good parents or genotypes. We aimed to verify the genetic diversity and behavior of cherry tomato genotypes and, using that, select potential parents to foster a future cherry tomato breeding programs.

\section{MATERIAL AND METHODS}

The experiment was conducted on the vegetable's experimental station of Federal University of Uberlândia (UFU), located in Monte CarmeloMG (18'42'43”'S, 47²9'56”W, 873 m altitude). Seedlings were produced in polystyrene trays, with 128 cells, filled with commercial substrate of coconut fiber, on January $20^{\text {th }}$. Seedlings were transplanted, 31 days after sowing, into five liter pots, filled with the same substrate used to produce seedlings. Each experimental plot consisted of two pots, arranged in sequence and spaced $0.1 \mathrm{~m}$ apart, having three plants per pot, totalizing 252 plants in the greenhouse, equivalent to 1.72 plants $\mathrm{m}^{-2}$. The greenhouse measures $7 \times 21 \mathrm{~m}$ and it's ceiling $4.0 \mathrm{~m}$. The greenhouse was covered with transparent polyethylene film of 150 micron, additivated against ultraviolet rays and side curtains of white and anti-aphid screen.

Genotypes consisted of 41 cherry tomatoes from germplasm bank of UFU. These materials are characterized by grape fruits of indeterminate growth habit. The pre-commercial genotype UFU 200 was used as check treatment due to its good acceptance by producers, having indeterminate growth habit and late maturation.

Cultural traits were realized as soon as needed and according to recommendation for tomato cropping on greenhouses (Alvarenga, 2013). Plants were conducted with only one stem, using ribbons in order to upright them. When the plants reached two meters height, the apical meristems of them were cut, stopping their growth and accelerating the ripening of fruits.

During the experiment, pest and diseases were monitored and, if necessary, chemical control was performed. Plants were irrigated daily, in three or four times, according to plant's necessity. After transplant, between the first and eighth week, commercial nutrients were provided, by fertirrigation, in the proportion of $1.0 ; 1.2 ; 1.0$ of NPK. After the ninth week, the system was changed to 1.0 ; $0.7 ; 2.0$ of NPK. During flowering, a leaf fertilization with calcium and boron was done, once a week, aiming to increase the number and size of flowers. Other essential nutrients were not supplied, due to be already in acceptable concentrations in the used substrate. Mature fruits were harvested weekly, during the period from April $20^{\text {th }}$ to June $08^{\text {th }}$.

The evaluated agronomic characteristics were: Average fruit weight $[(\mathrm{g})$ ratio between total mass of each plot and number of fruits harvested in each one]; Productivity $\left[\left(\mathrm{kg} \mathrm{plant}^{-1}\right)\right.$ ratio between harvested fruit weight and number of plants on each plot]; Number of fruits per plant (fruits plant $\left.^{-1}\right)$; Stem diameter $[(\mathrm{mm})$ measured in the region between the third and fourth inflorescence]; Length of internode $[(\mathrm{cm})$, measured on the region between all nodes, starting on the first bifurcation and finishing on the last leaf]; Total soluble solids $\left[\left({ }^{\circ} \mathrm{Brix}\right)\right.$ average value of five fruits that were harvested in each plant, on the $110^{\text {th }}$ day after sowing, with the aid of a digital refractometer (Atago PAL-1 3810)]; Total leaf chlorophyll during flowering and fruiting [(ICC), Falkerdo index of total chlorophyll, sum of chlorophyll a with chlorophyll $b$, measured on a leaf surface, at 59 and 90 days after sowing, respectively, $0.02 \mathrm{~m}$ away from the edge and $0.05 \mathrm{~m}$ away from the center, with the aid of a digital chlorophyllometer (Clorofilog, CFL 1030 Falker)]; Fruit diameter $[(\mathrm{mm})$ ratio between five fruits harvested in each plot, on 110 DAS]; Precocity index $[(\%)$ ratio between sum of mass of all harvested fruits, from the first two harvests, multiplied by 100].

The experimental design was of randomized complete block design, with 42 treatments and two replications. Data were submitted to analyze of variance, by the $F$ test $(p=0.05)$. Averages were compared in two different ways: using Scott-Knott test $(\mathrm{p}=0.05)$ and Dunnett test $(p=0.05)$, in order to compare the performance of genotypes with each other and, individually with the check treatment, respectively. After that, multivariate analyzes were done, aiming to determinate the genetic dissimilarity between the genotypes, getting with this, a dissimilarity matrix produced by the generalized distance of Mahalanobis $\left(\mathrm{D}_{\text {ii }}^{2}\right)$.

Genetic diversity was represented by a dendrogram obtained by hierarquic method of Unweighted Pair-Group Method Using Arithmetic Averages (UPGMA) and by Tocher method. Grouping validation by UPGMA method was obtained by the coefenetic coefficient of correlation (CCC), calculated by the Mantel test (1967). The relative contribution of the quantitative characters was calculated according to Singh criterion (1981). All data were analysed using software GENES v. 2015.5.0 (Cruz, 2013).

\section{RESULTS AND DISCUSSION}

Genotypes differed from each other (Scott-Knott test, 5\% probability) for total leaf chlorophyll (flowering and fruiting), stem diameter, fruit diameter, average fruit weight and productivity (Table 1). The comparison of each genotype individually to the check treatment (Dunnett test, $5 \%$ probability), for number of fruits, total soluble solids and precocity index, also showed significant difference from each other. On the other hand, for internode length (average of $9.6 \mathrm{~cm}$ ) no significant 
Table 1. Averages of total chlorophyll content, during flowering (TCFL) and fruiting (TCFR), stem diameter (SD), soluble solids content (SSC), fruit diameter (FD), number of fruits (NF), productivity (P), average fruit weight (AFW) and precocity index (PI), in 42 cherry tomato genotypes. Monte Carmelo, UFU, 2016.

\begin{tabular}{|c|c|c|c|c|c|c|c|c|c|}
\hline Genotypes & TCFL (ICC) & TCFR (ICC) & $\mathrm{SD}(\mathrm{mm})$ & SSC ( ${ }^{\circ}$ Brix) & FD (mm) & NF (fruit pl $^{-1}$ ) & $\mathbf{P}\left(\mathrm{g} \mathrm{pl}^{-1}\right)$ & AFW (g) & PI (\%) \\
\hline UFU 01 & $48.8 \mathrm{~b}+$ & $52.7 \mathrm{a}$ & $6.1 \mathrm{~d}+$ & $6.3 \mathrm{a}$ & $23.3 \mathrm{~b}$ & $57.0 \mathrm{a}+$ & $551.6 \mathrm{a}+$ & $9.8 \mathrm{c}$ & $28.9 \mathrm{a}$ \\
\hline UFU 02 & $55.8 \mathrm{~b}$ & $52.0 \mathrm{a}$ & $5.3 \mathrm{e}+$ & $6.9 \mathrm{a}$ & $22.6 \mathrm{~b}$ & $43.4 \mathrm{a}$ & $376.5 \mathrm{~b}$ & $8.6 \mathrm{c}$ & $48.7 \mathrm{a}+$ \\
\hline UFU 03 & $62.4 \mathrm{a}$ & $56.3 \mathrm{a}$ & $6.2 \mathrm{~d}+$ & $5.7 \mathrm{a}$ & $26.7 \mathrm{a}$ & $44.9 \mathrm{a}$ & $408.8 \mathrm{a}$ & $9.1 \mathrm{c}$ & $29.4 \mathrm{a}$ \\
\hline UFU 04 & $60.7 \mathrm{a}$ & $56.4 \mathrm{a}$ & $5.3 \mathrm{e}+$ & $6.8 \mathrm{a}$ & $25.9 \mathrm{a}$ & $34.8 \mathrm{a}$ & $366.0 \mathrm{~b}$ & $10.5 \mathrm{c}$ & $34.1 \mathrm{a}$ \\
\hline UFU 05 & $57.5 \mathrm{a}$ & $54.9 \mathrm{a}$ & $6.5 \mathrm{~d}+$ & $7.0 \mathrm{a}$ & $24.3 b$ & $42.7 \mathrm{a}$ & $438.7 \mathrm{a}$ & $10.6 \mathrm{c}$ & $40.1 \mathrm{a}+$ \\
\hline UFU 06 & $55.5 \mathrm{~b}$ & $53.7 \mathrm{a}$ & $6.5 \mathrm{~d}+$ & $6.4 \mathrm{a}$ & $23.5 \mathrm{~b}$ & $49.8 \mathrm{a}+$ & $514.2 \mathrm{a}+$ & $10.2 \mathrm{c}$ & $32.6 \mathrm{a}$ \\
\hline UFU 07 & $55.0 \mathrm{~b}$ & $48.7 \mathrm{~b}$ & $6.0 \mathrm{~d}+$ & $5.3 \mathrm{a}$ & $28.3 \mathrm{a}$ & $46.8 \mathrm{a}^{+}$ & $484.4 \mathrm{a}+$ & $11.0 \mathrm{~b}$ & $42.4 \mathrm{a}+$ \\
\hline UFU 08 & $60.9 \mathrm{a}$ & $47.4 \mathrm{~b}$ & $6.7 \mathrm{~d}+$ & $5.6 \mathrm{a}$ & $27.7 \mathrm{a}$ & $30.0 \mathrm{a}$ & $302.8 \mathrm{~b}$ & $10.2 \mathrm{c}$ & $53.3 \mathrm{a}+$ \\
\hline UFU 09 & $59.7 \mathrm{a}$ & $59.8 \mathrm{a}$ & $6.0 \mathrm{~d}+$ & $5.5 \mathrm{a}$ & $24.0 \mathrm{~b}$ & $51.5 \mathrm{a}+$ & $449.7 \mathrm{a}+$ & $8.7 \mathrm{c}$ & $24.0 \mathrm{a}$ \\
\hline UFU 10 & $60.5 \mathrm{a}$ & $58.6 \mathrm{a}$ & $5.8 \mathrm{~d}+$ & $6.4 \mathrm{a}$ & $24.0 \mathrm{~b}$ & $51.6 \mathrm{a}+$ & $474.1 \mathrm{a}+$ & $9.2 \mathrm{c}$ & $31.0 \mathrm{a}$ \\
\hline UFU 11 & $59.1 \mathrm{a}$ & $52.3 \mathrm{a}$ & $5.5 \mathrm{e}+$ & $5.9 \mathrm{a}$ & $23.2 \mathrm{~b}$ & $33.5 \mathrm{a}$ & $284.5 \mathrm{~b}$ & $8.6 \mathrm{c}$ & $53.8 \mathrm{a}+$ \\
\hline UFU 12 & $55.0 \mathrm{~b}$ & $51.6 \mathrm{a}$ & $6.1 \mathrm{~d}+$ & $5.1 \mathrm{a}$ & $29.3 \mathrm{a}$ & $32.3 \mathrm{a}$ & $436.1 \mathrm{a}$ & $13.7 \mathrm{a}$ & $42.7 \mathrm{a}+$ \\
\hline UFU 13 & $57.3 \mathrm{a}$ & $56.0 \mathrm{a}$ & $7.4 \mathrm{c}+$ & $6.2 \mathrm{a}$ & $25.7 \mathrm{a}$ & $48.6 \mathrm{a}^{+}$ & $411.4 \mathrm{a}$ & $8.5 \mathrm{c}$ & $28.8 \mathrm{a}$ \\
\hline UFU 14 & $58.2 \mathrm{a}$ & $52.2 \mathrm{a}$ & $5.4 \mathrm{e}+$ & $4.8 \mathrm{a}$ & $29.5 \mathrm{a}$ & $32.9 \mathrm{a}$ & $482.9 \mathrm{a}+$ & $14.7 \mathrm{a}$ & $33.1 \mathrm{a}$ \\
\hline UFU 15 & $59.0 \mathrm{a}$ & $50.6 \mathrm{~b}$ & $6.5 \mathrm{~d}+$ & $6.4 \mathrm{a}$ & $24.9 \mathrm{~b}$ & $31.4 \mathrm{a}$ & $357.9 \mathrm{~b}$ & $11.5 \mathrm{~b}$ & $47.2 \mathrm{a}+$ \\
\hline UFU 16 & $58.9 \mathrm{a}$ & $51.4 \mathrm{a}$ & $5.3 \mathrm{e}+$ & $5.7 \mathrm{a}$ & $26.5 \mathrm{a}$ & $30.7 \mathrm{a}$ & $433.7 \mathrm{a}$ & $14.2 \mathrm{a}$ & $40.6 \mathrm{a}+$ \\
\hline UFU 17 & $55.4 \mathrm{~b}$ & $55.2 \mathrm{a}$ & $5.1 \mathrm{e}^{+}$ & $6.2 \mathrm{a}$ & $25.2 \mathrm{~b}$ & $48.3 \mathrm{a}+$ & $556.9 \mathrm{a}+$ & $11.5 \mathrm{~b}$ & $39.4 \mathrm{a}+$ \\
\hline UFU 18 & $55.8 \mathrm{~b}$ & $49.2 \mathrm{~b}$ & $5.0 \mathrm{e}+$ & $5.5 \mathrm{a}$ & $26.5 \mathrm{a}$ & $36.5 \mathrm{a}$ & $427.4 \mathrm{a}$ & $11.8 \mathrm{~b}$ & $43.9 \mathrm{a}+$ \\
\hline UFU 19 & $56.4 \mathrm{~b}$ & $51.9 \mathrm{a}$ & $5.1 \mathrm{e}+$ & $5.7 \mathrm{a}$ & $27.4 \mathrm{a}$ & $34.0 \mathrm{a}$ & $393.2 \mathrm{~b}$ & $11.6 \mathrm{~b}$ & $39.4 \mathrm{a}+$ \\
\hline UFU 20 & $56.4 \mathrm{~b}$ & $53.2 \mathrm{a}$ & $6.7 \mathrm{~d}+$ & $5.0 \mathrm{a}$ & $27.8 \mathrm{a}$ & $38.6 \mathrm{a}$ & $304.2 \mathrm{~b}$ & $8.0 \mathrm{c}$ & $27.3 \mathrm{a}$ \\
\hline UFU 21 & $51.4 \mathrm{~b}$ & $46.9 \mathrm{~b}$ & $5.5 \mathrm{e}+$ & $5.5 \mathrm{a}$ & $28.6 \mathrm{a}$ & $43.1 \mathrm{a}$ & $527.2 \mathrm{a}+$ & $12.3 \mathrm{~b}$ & $52.5 \mathrm{a}+$ \\
\hline UFU 22 & $52.2 \mathrm{~b}$ & $48.2 \mathrm{~b}$ & $7.1 \mathrm{c}+$ & $6.2 \mathrm{a}$ & $23.5 b$ & $38.7 \mathrm{a}$ & $397.4 \mathrm{~b}$ & $10.4 \mathrm{c}$ & $34.9 \mathrm{a}$ \\
\hline UFU 23 & $51.8 \mathrm{~b}$ & $45.5 \mathrm{~b}$ & $7.0 \mathrm{c}+$ & $6.8 \mathrm{a}$ & $25.5 \mathrm{a}$ & $37.7 \mathrm{a}$ & $383.8 \mathrm{~b}$ & $10.3 \mathrm{c}$ & $30.3 \mathrm{a}$ \\
\hline UFU 24 & $53.4 \mathrm{~b}$ & $55.8 \mathrm{a}$ & $8.2 \mathrm{~b}+$ & $7.3 \mathrm{a}+$ & $24.2 \mathrm{~b}$ & $51.7 \mathrm{a}+$ & $416.4 \mathrm{a}$ & $8.1 \mathrm{c}$ & $18.0 \mathrm{a}$ \\
\hline UFU 25 & $50.8 \mathrm{~b}$ & $48.2 \mathrm{~b}$ & $6.6 \mathrm{~d}+$ & $6.8 \mathrm{a}$ & $23.6 \mathrm{~b}$ & $43.4 \mathrm{a}$ & $356.1 \mathrm{~b}$ & $8.3 \mathrm{c}$ & $26.0 \mathrm{a}$ \\
\hline UFU 26 & $52.1 \mathrm{~b}$ & $43.2 \mathrm{~b}$ & $5.7 \mathrm{e}+$ & $8.3 \mathrm{a}+$ & $22.0 \mathrm{~b}$ & $49.3 \mathrm{a}+$ & $400.4 \mathrm{~b}$ & $8.1 \mathrm{c}$ & $30.7 \mathrm{a}$ \\
\hline UFU 27 & $52.2 \mathrm{~b}$ & $40.7 \mathrm{~b}+$ & $8.3 \mathrm{~b}+$ & $6.7 \mathrm{a}$ & $24.8 \mathrm{~b}$ & $43.5 \mathrm{a}$ & $326.1 \mathrm{~b}$ & $7.4 \mathrm{c}+$ & $36.5 \mathrm{a}+$ \\
\hline UFU 28 & $60.6 \mathrm{a}$ & $56.8 \mathrm{a}$ & $6.2 \mathrm{~d}+$ & $6.6 \mathrm{a}$ & $23.6 \mathrm{~b}$ & $32.7 \mathrm{a}$ & $319.0 \mathrm{~b}$ & $9.8 \mathrm{c}$ & $31.9 \mathrm{a}$ \\
\hline UFU 29 & $54.2 \mathrm{~b}$ & $49.2 \mathrm{~b}$ & $6.6 \mathrm{~d}+$ & $5.9 \mathrm{a}$ & $22.9 \mathrm{~b}$ & $42.5 \mathrm{a}$ & $497.3 \mathrm{a}+$ & $11.8 \mathrm{~b}$ & $43.3 \mathrm{a}+$ \\
\hline UFU 30 & $48.4 \mathrm{~b}+$ & $53.2 \mathrm{a}$ & $6.1 \mathrm{~d}+$ & $5.5 \mathrm{a}$ & $26.4 \mathrm{a}$ & $22.8 \mathrm{a}$ & $331.0 \mathrm{~b}$ & $14.4 \mathrm{a}$ & $12.9 \mathrm{a}$ \\
\hline UFU 31 & $60.8 \mathrm{a}$ & $57.0 \mathrm{a}$ & $5.7 \mathrm{e}+$ & $6.1 \mathrm{a}$ & $23.5 \mathrm{~b}$ & $29.5 \mathrm{a}$ & $267.9 \mathrm{~b}$ & $9.0 \mathrm{c}$ & $26.8 \mathrm{a}$ \\
\hline UFU 32 & $63.0 \mathrm{a}$ & $55.3 \mathrm{a}$ & $5.4 \mathrm{e}+$ & $6.4 \mathrm{a}$ & $23.3 \mathrm{~b}$ & $35.5 \mathrm{a}$ & $313.2 \mathrm{~b}$ & $8.7 \mathrm{c}$ & $30.3 \mathrm{a}$ \\
\hline UFU 33 & $60.5 \mathrm{a}$ & $55.9 \mathrm{a}$ & $5.5 \mathrm{e}+$ & $5.6 \mathrm{a}$ & $24.5 \mathrm{~b}$ & $32.4 \mathrm{a}$ & $304.3 \mathrm{~b}$ & $10.4 \mathrm{c}$ & $32.9 \mathrm{a}$ \\
\hline UFU 34 & $57.5 \mathrm{a}$ & $56.5 \mathrm{a}$ & $5.1 \mathrm{e}+$ & $6.0 \mathrm{a}$ & $23.4 \mathrm{~b}$ & $39.2 \mathrm{a}$ & $372.3 \mathrm{~b}$ & $9.4 \mathrm{c}$ & $45.4 \mathrm{a}+$ \\
\hline UFU 35 & $61.9 \mathrm{a}$ & $49.0 \mathrm{~b}$ & $6.2 \mathrm{~d}+$ & $6.8 \mathrm{a}$ & $23.6 \mathrm{~b}$ & $33.3 \mathrm{a}$ & $281.5 \mathrm{~b}$ & $8.5 \mathrm{c}$ & $28.2 \mathrm{a}$ \\
\hline UFU 36 & $59.8 \mathrm{a}$ & $54.7 \mathrm{a}$ & $5.1 \mathrm{e}+$ & $5.7 \mathrm{a}$ & $24.3 \mathrm{~b}$ & $41.4 \mathrm{a}$ & $339.8 \mathrm{~b}$ & $8.3 \mathrm{c}$ & $32.4 \mathrm{a}$ \\
\hline UFU 37 & $56.2 \mathrm{~b}$ & $58.4 \mathrm{a}$ & $6.2 \mathrm{~d}+$ & $5.5 \mathrm{a}$ & $22.7 \mathrm{~b}$ & $38.6 \mathrm{a}$ & $383.1 \mathrm{~b}$ & $9.9 \mathrm{c}$ & $27.8 \mathrm{a}$ \\
\hline UFU 38 & $62.8 \mathrm{a}$ & $45.4 \mathrm{~b}$ & $4.5 \mathrm{e}+$ & $5.8 \mathrm{a}$ & $23.1 \mathrm{~b}$ & $38.5 \mathrm{a}$ & $382.9 \mathrm{~b}$ & $9.9 \mathrm{c}$ & $43.4 \mathrm{a}+$ \\
\hline UFU 39 & $59.8 \mathrm{a}$ & $57.6 \mathrm{a}$ & $6.1 \mathrm{~d}+$ & $5.8 \mathrm{a}$ & $25.4 \mathrm{~b}$ & $34.6 \mathrm{a}$ & $336.2 \mathrm{~b}$ & $10.4 \mathrm{c}$ & $27.8 \mathrm{a}$ \\
\hline UFU 40 & $59.8 \mathrm{a}$ & $48.9 \mathrm{~b}$ & $7.1 \mathrm{c}+$ & $6.5 \mathrm{a}$ & $26.4 \mathrm{a}$ & $44.9 \mathrm{a}$ & $358.6 \mathrm{~b}$ & $7.9 \mathrm{c}$ & $27.8 \mathrm{a}$ \\
\hline UFU 41 & $53.5 \mathrm{~b}$ & $50.3 \mathrm{a}$ & $6.3 \mathrm{~d}+$ & $6.5 \mathrm{a}$ & $23.9 \mathrm{~b}$ & $46.7 \mathrm{a}+$ & $489.1 \mathrm{a}+$ & $10.5 \mathrm{c}$ & $48.6 \mathrm{a}+$ \\
\hline UFU 200 & $61.0 \mathrm{a}$ & $52.3 \mathrm{a}$ & $10.3 \mathrm{a}$ & $4.9 \mathrm{a}$ & $25.6 \mathrm{a}$ & $17.8 \mathrm{a}$ & $213.7 \mathrm{~b}$ & $12.2 \mathrm{~b}$ & $3.5 \mathrm{a}$ \\
\hline $\mathrm{CV}(\%)$ & 5.69 & 6.65 & 7.65 & 11.94 & 6.27 & 21.23 & 18.44 & 13.36 & 29.23 \\
\hline
\end{tabular}

Averages followed by different letters, in column, differ from each other by Scott-Knott test, 0.05 . + differ from check treatment by the Dunnett test, 0.05. 
difference was detected trough $\mathrm{F}$ test $(\mathrm{p}=0.05)$.

Overall, total leaf chlorophyll during the flowering and fruiting, varied from 48.4 to 62.8 ICC and from 40.7 to $59.8 \mathrm{ICC}$, respectively; the stem diameter varied from 5.1 to $10.3 \mathrm{~mm}$; fruit diameter from 22.6 to $29.3 \mathrm{~mm}$; average fruit weight from 7.4 to $14.7 \mathrm{~g}$ and productivity from 213.7 to $556.9 \mathrm{~g}$ plant $^{-1}$, an indicative of high diversity among genotypes.

Among the 41 evaluated genotypes, ten (UFU 09, UFU 10, UFU 14, UFU 29, UFU 21, UFU 07, UFU 06, UFU 01, UFU 17 and UFU 41) presented two times productivity of the check cultivar (Dunnett test). These cultivars presented a variation of productivity from 449.7 to $556.9 \mathrm{~g} \mathrm{plant}^{-1}$, similar to the results found by Menezes et al. (2010), evaluating cherry tomatoes in the field. Among the 10 genotypes that highlighted for productivity, five (UFU 21, UFU 29, UFU 17, UFU 41 and UFU 07) were also the earliest, all presenting more than $39 \%$ of total yield $\left(\mathrm{g} \mathrm{plant}^{-1}\right)$ in the first and second harvests, different from check treatment, which got only $3.5 \%$ of the total yield during the first two harvests. Precocity and high level of productivity are two of the main desired characteristics in a cherry tomato genotype.

Total soluble solids is an important feature of cherry tomato. The higher the soluble solids, the sweeter the fruit flavor, being the genotypes with high ${ }^{0}$ Brix the most chosen by the consumers (Schwarzer et al., 2013; Maciel et al., 2015). On this sense, only genotypes

Table 2. Grouping representation obtained by the optimization of Tocher, based on Mahalanobis distance, estimated from ten characteristics, evaluated on all 42 tomato genotypes. Monte Carmelo, UFU, 2016.

\begin{tabular}{|c|c|}
\hline Groups & Genotypes \\
\hline I & 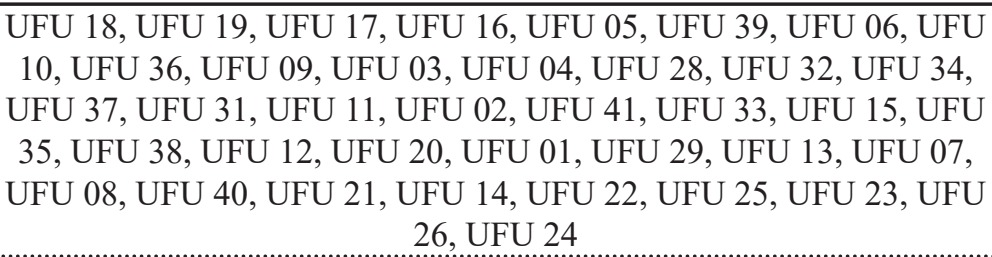 \\
\hline II & UFU 30 \\
\hline III & UFU 27 \\
\hline IV & UFU 200 (check treatment) \\
\hline
\end{tabular}

into different groups, using dissimilarity measures, helps the breeders to select good progenitors (Araujo et al., 2016). The genetic dissimilarity measures by the generalized distance of Mahalanobis $\left(\mathrm{D}_{\mathrm{ii}}^{2}\right)$, of the 42 cherry tomato genotypes, vary between 2.08 (UFU 18 and UFU 19) and 242.4 (UFU 38 and UFU 200), an indicative of high genetic diversity.

The formation of groups, represented by a dendrogram, using the UPGMA method (Figure 1), showed a correlation coefficient of 0.85 , significative for a $t$ test $(\mathrm{p}<0.01)$. So, it is possible to affirm that the dendogram reproduced, in a satisfactory way, the information contained in the matrix and, consequently, in the formation of groups. Grouping separation was done by delimitation of a cut line of $50 \%$, established in the place of an abrupt change on the dendogram ramification (Cruz et al., 2012). With this cut, the genotypes formed four distinct groups, being group I composed of $93 \%$ of the cherry tomato genotypes, group II formed of the genotype UFU 30, III of the genotype UFU 27 and the fourth group was formed by the check treatment (UFU 200).

Analyzing the group formation by the method of Tocher, it was possible to see that it also separates genotypes into four different groups (Table 2). According to Gonçalves et al. (2008) and Araujo et al. (2016), UPGMA method is efficient on the formation of groups as well as Tocher method (Mattedi et al., 2014).

Genotypes UFU 30, UFU 27 and UFU 200 can be used as progenitors, due to their divergence in relation to the others. Genotypes UFU 27 and UFU 200 highlighted for stem diameter, showed the highest values $(8.3$ and $10.3 \mathrm{~mm}$, respectively), a fact that may justify their separation into different groups. On the other hand, UFU 30 presented the highest average fruit weight (14.4 $\mathrm{g})$. This hypothesis is confirmed by the relative contribution of characters (Table 3). Stem diameter was responsible for the highest relative contribution of the genotypes divergence, with $31 \%$ of the total variability. Chlorophyll content on leaves was also relevant and sum to the values of average fruit 
Table 3. Relative contribution of ten agronomic characters, on the genetic diversity of 42 cherry tomato genotypes, according to Singh (1981). Monte Carmelo, UFU, 2016.

\begin{tabular}{lcc}
\hline Characteristics $^{\mathbf{1}}$ & $\mathbf{S . j}$ & $\mathbf{S . j} \mathbf{j}(\mathbf{\%})$ \\
\hline TCFL & 4666.82 & 11.44 \\
TCFR & 5598.90 & 13.73 \\
SD & 12469.63 & 30.58 \\
LI & 2275.63 & 5.58 \\
SSC & 1376.62 & 3.38 \\
FD & 3226.28 & 7.91 \\
NF & 54.72 & 0.13 \\
P & 4208.96 & 10.32 \\
AFW & 3996.88 & 9.80 \\
PI & 2909.55 & 7.13 \\
\hline
\end{tabular}

${ }^{1}$ TCFL and TCFR $=$ Total chlorophyll during flowering and fruiting, respectively; $\mathrm{SD}=$ stem diameter; $\mathrm{LI}=$ lenght of internodes; $\mathrm{SSC}=$ soluble solids contente; $\mathrm{FD}=$ fruit diameter; $\mathrm{NF}=$ number of fruits; $\mathrm{P}=$ productivity; $\mathrm{AFW}=$ average fruit weight and $\mathrm{PI}=$ precocity index.

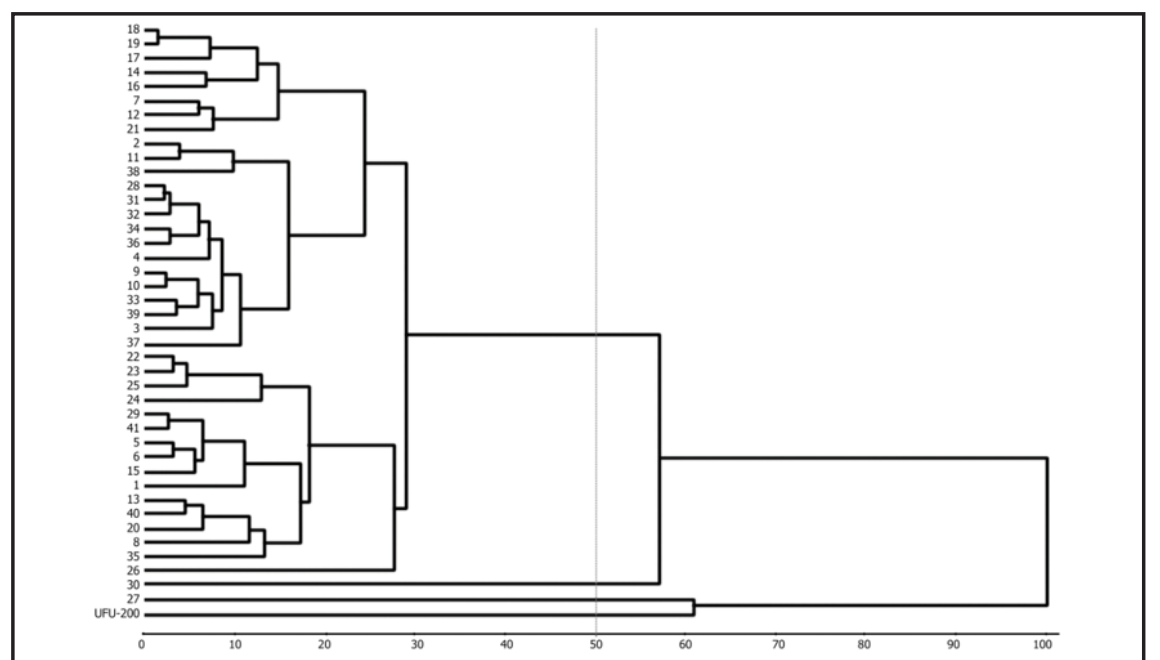

Figure 1. Dendogram of genetic diversity among 42 cherry tomato genotypes, obtained by UPGMA hierarquic method; UFU $200=$ check cultivar; the other numbers indicate the genotypes. Monte Carmelo, UFU, 2016.

weight, productivity and stem diameter influenced $76 \%$ of the genetic diversity. On the other hand, number of fruits contributed with only $0.1 \%$, being, therefore, the variable selected for discarding, according to Singh (1981). In other tomato groups, the number of fruits is one of the most important characters in the contribution of genetic diversity (Araújo et al., 2016). These informations help the breeder to choose which evaluation is important to be done in a breeding program, reducing time and efforts.

In order to select good progenitors, breeders explore commercial and pre- commercial cultivars, with agronomic characters of interest. The divergence of the check treatment (UFU 200), in relation to others, represents a possibility and viability of it to be used in a breeding program of cherry tomato. Therefore, when crossing genotypes that have a good agronomic behavior, as UFU 21, UFU 29 and UFU 07 with UFU 200, it would be possible to obtain hybrids with better characteristics, like soluble solids content, productivity and precocity and, consequently, with high commercial potential.

In general, the methods of multivariate analyzes (UPGMA and
Tocher), that were used to estimated the genetic dissimilarity, were similar and satisfactory, being important tools to find good progenitors. The univariate analyzes, by the Scott-Knott test, did not allow an explicit visualization of divergent groups, which makes the association of uni and multivariate techniques an important strategy in order to determine genetic variability between cherry tomato genotypes (Araújo et al., 2016).

It is possible to affirm that genotypes UFU 41, UFU 29, UFU 21, UFU 17 and UFU 07 are more productive, early and also genetically divergent from the commercial access, making them possible genitors.

\section{REFERENCES}

ABRAHÃO, C; VILLAS BÔAS, RL; BULL, LT. 2014. Relação $\mathrm{K}: \mathrm{Ca}: \mathrm{Mg}$ na solução nutritiva para a produção de minitomate cultivado em substrato. Irriga 19: 214-224.

ALVARENGA, MAR. 2013.Tomate, Produção em campo, casa de vegetação e hidroponia. Lavras:UFLA. $455 \mathrm{p}$.

ARAUJO, JC; TELHADO, SFP; SAKAI, RH; LEDO, CAS; MELO, PCT. 2016. Univariate and multivariate procedures for agronomic evaluation of organically grown tomato cultivars. Horticultura Brasileira 34: 374-380.

ASSOCIAÇÃO BRASILEIRA DE COMÉRCIO DE SEMENTES E MUDAS - ABCSEM. 2014. Dados do setor de pesquisa de mercado de sementes de hortaliças. Available at $<\mathrm{http}: / /$ www.abcsem.com.br/dadosdosegmento.php> Accessed September 22, 2016.

BORÉM, A; MIRANDA, GV. 2009. Melhoramento de plantas. Viçosa: UFV. $449 \mathrm{p}$.

CRUZ, CD. 2013. GENES: A software package for analysis in experimental statistics and quantitative genetics. Acta Scientiarum 35: 271-276.

CRUZ, CD; REGAZZI, AJ; CARNEIRO, PCS. 2012. Modelos biométricos aplicados ao melhoramento genético. Viçosa: UFV. 514p.

FERREIRA, MMM; FERREIRA, GB; FONTES, PCR; DANTAS, JP. 2006. Índice spad e teor de clorofila no limbo foliar do tomateiro em função de doses de nitrogênio e da adubação orgânica, em duas épocas de cultivo. Revista Ceres 53: 83-92.

GARCIA, E; BARRETT, DM. 2006. Assessing lycopene content in California processing tomatoes. Journal of Food Processing and Preservation 30: 56-70.

GONÇALVES, LSA; RODRIGUES, R; SUDRÉ, CP; BENTO, CS; MOULIN, MM; ARAÚJO, ML; DAHER, RF; PEREIRA, TNS; PEREIRA, MG. 2008. Divergência genética 
em tomate estimada por marcadores RAPD em comparação com descritores multicategóricos. Horticultura Brasileira 26: 364-370.

MACIEL, GM; FERNANDES, MAR; HILLEBRAND, V; AZEVEDO, BNR. 2015.

Influência da época de colheita no teor de sólidos solúveis em frutos de minitomate. Scientia Plena 11: 1-6.

MACIEL, GM; FERNANDES, MAR; MELO, OD; OLIVEIRA, CS. 2016. Potencial agronômico de híbridos de minitomate com hábito de crescimento determinado e indeterminado. Horticultura Brasileira 34: 144-148.
MANTEL, N. 1967. The detection of disease clustering and a generalized regression approach. Cancer Research 27: 209-220.

MATTEDI, AP; GUIMARÃES, MA; NICK, C; SILVA, DJH; PUIATTI, M; CARNEIRO, PCS. 2014. Genetic divergence of tomato subsamples. Revista Ceres 61: 70-76.

MENEZES, JBC; COSTA, CA; SAMPAIO, RA; CATÃO, HCM; GUILHERME, DO; MARTINEZ, RAS. 2012. Fruit production and classification of four cherry tomato genotypes under an organic cropping system. IDESIA 30: 29-35.

SCHWARZ, K; RESENDE, JTV; PRECZENHAK,
AP; PAULA, JT; FARIA, MV; DIAS, DM. 2013. Desempenho agronômico e qualidade físico-química de híbridos de tomateiro em cultivo rasteiro. Horticultura Brasileira 31: 410-418.

SINGH, D. 1981. The relative importance of characters affecting genetic divergence. The Indian Journal of Genetic and Plant Breeding 41: 237-245.

WOOD, CW; REEVES, DW; HIMELRICK, DJ. 1993. Relationships between chlorophyll meter readings and leaf chlorophyll concentration, $\mathrm{N}$ status, and crop yield: a review. Proceedings Agronomy Society of New Zealand 23: 1-9. 